\title{
Sea breeze front identification on the northeastern coast of Brazil and its implications for meteorological conditions in the Sergipe region
}

\author{
$\operatorname{Max}_{\text {Anjos }}{ }^{1}$ (D) António Lopes ${ }^{1}$
}

Received: 30 October 2017 / Accepted: 26 November 2018 / Published online: 6 December 2018

(C) The Author(s) 2018

\begin{abstract}
The common idea that the sea breeze is a phenomenon that is always beneficial to the thermal from point of view is questioned in this study, since the sea breeze front (SBF) development is related with warmer days in the Sergipe region, located in the northeastern coast of Brazil. For this reason, the first climatology of the SBF and its potential implications on meteorological conditions were presented by using remote sensing (GOES-13 satellite image) and surface meteorological data. Results showed daily performance of the SBF: onset at 12:00 UTC and cessation at 19:00 UTC corresponding to a duration of $7 \mathrm{~h}$, mean strength of $3.6 \mathrm{~ms}^{-1}$, and maximum inland penetration of $94 \mathrm{~km}$ from coast. In addition, we also observed SBF passage is related with an average increase in solar radiation $\left(84 \mathrm{~W} \mathrm{~m}^{-2}\right)$, temperature $\left(1^{\circ} \mathrm{C}\right)$, and a decrease in relative humidity $(10 \%)$ and dew point temperature $\left(1^{\circ} \mathrm{C}\right)$. We hypothesize that, in certain circumstances, the SBF development is not beneficial for human thermal comfort in the Sergipe region.
\end{abstract}

\section{Introduction}

Sea breeze is considered a fundamental atmospheric phenomenon for many coastal regions due to its influence on local weather and climate. Sea breeze structure, behavior, and characteristics have fascinated many scientists for at least a hundred years, which has made it one of the most extensively studied climate systems on several coastal regions of the world (Azorin-Molina et al. 2011; Franchito et al. 1998; Freitas et al. 2009; Furberg et al. 2002; Huang et al. 2016; Naor et al. 2017; Oliveira et al. 2003; Perez and Silva Dias 2017; Simpson et al. 1977; Teli 2003).

Max Anjos

maxanjos@campus.ul.pt

António Lopes

antonio.lopes@campus.ul.pt

1 Institute of Geography and Spatial Planning (IGOT-ULisboa), Center of Geographical Studies (Climate Change and Environmental Systems Research Group), University of Lisbon, Lisbon, Portugal
Because of the smaller effect of the Coriolis force, the landsea temperature difference for sea breeze occurrence must be above $4{ }^{\circ} \mathrm{C}$ in the intertropical latitudes (Cautenet and Rosset 1989; Okoola 1978), rather than $6^{\circ} \mathrm{C}$ in the temperate and high latitudes. Besides diurnal changes of wind speed and direction, the sea breeze is usually accompanied by a humidity rise and a temperature drop, which are associated with the heat transported through the sea's cool air (Atkinson 1981; Simpson 1994). As a consequence, many studies have revealed the strong interaction between the sea breeze and thermal local patterns in urban areas, namely the urban heat island (Acero et al. 2013; Dandou et al. 2009; Freitas et al. 2006; Meir et al. 2013; Papanastasiou et al. 2010; Sasaki et al. 2017; Thompson et al. 2007; Vemado and Pereira Filho 2016; Yamato et al. 2017; Yoshikado 1990) as well as recognizing it as a positive climate element to alleviate human thermal stress (Emmanuel and Johansson 2006; Lopes et al. 2011; Papanastasiou et al. 2010; Sasaki et al. 2017; Yamato et al. 2017).

Surprisingly, even with the overabundance of studies in the literature, there are still several critical questions regarding the influence of the sea breeze on meteorological conditions that have not been discussed in depth. Several studies have shown that the sea breeze can be associated with adverse meteorological conditions, such as complex situations for air pollution by transport and dispersion processes (Clappier et al. 2000; 
Mavrakou et al. 2012; Papamanolis 2015; Papanastasiou and Melas 2009; Yimin and Lyons 2003), thunderstorm genesis (Bhate et al. 2016), fire whirl occurrence (Seto and Clements 2011), and effects on microwave propagation along the coastal belt (Radha Krishna Rao and Purnachandra Rao 2005; Reddy and Reddy 2007). However, few studies have given attention to the interaction between sea breeze and thermal effect by examining the temperature and solar radiation rises. Panchal's (1993) and Khan's (2010) studies are some of the few who have approached that issue. The first study showed that in the winter months (November to April), the temperature rises in Kalpakkam (India) during the pre-onset of sea breeze conditions, and consequently, the sea is warmer than the land due to the increase in insolation with the sunrise. The second study noticed that during sea breeze days on the Eastern and Western coast of the Auckland region (New Zealand), the solar radiation and temperature increased due to the Earth's surface overheating, resulting in warmer days. Thus, the common idea that the sea breeze could be an important mechanism to decrease the high temperatures in the northeastern coast of Brazil is questioned in this paper.

In general, the northeastern coast of Brazil has warm summers and mild winters, characterized by high temperature (mean of $27{ }^{\circ} \mathrm{C}$ ) and radiation solar (mean of $5 \mathrm{kWh} \mathrm{m}^{-2}$ day $^{-1}$ ) values throughout the year. In this context, the Sergipe region gains special interest because possible changes in solar radiation and temperature, especially in the warmer season, could have significant implications on meteorological conditions, e.g. human thermal stress.

Nowadays, modern knowledge considers the sea breeze as a system (Miller 2003). The sea breeze front (SBF) is one component of this system, and it is often associated with temperature drop and humidity rise, in which the air is forced to ascend and condensate in low-level atmosphere, allowing for the formation of a line of clouds parallel to the coast (Miller 2003; Simpson 1994). The spatial organization of this line of clouds and its progressive movement help to locate the SBF and compute its inland penetration. According to Bigot and Planchon (2003), SBF monitoring by remote sensing is useful to mark and draw the geographical position of the SBF and indirectly to estimate the strength and persistence of the sea breeze.

In the past few decades, the advances in remote sensing techniques have allowed for SBF to be studied more in depth (Banta et al. 1993; Crosman and Horel 2010; Damato et al. 2003; Gille 2003; Lensky and Dayan 2012; Phan and Manomaiphiboon 2012; Simpson 1966; Zhu and Atkinson 2004). By using satellite images, we can have a potential signature of the sea breeze, where a line of clouds parallel to the coast and associated with the SBF is observed over the image. Damato et al. (2003) used visible images from the Advanced Very High Resolution Radiometer (AVHRR) to identify the SBF in the English Channel region from May to September 2000. Their study demonstrated that the SBF inland penetration varied between 10 and
$50 \mathrm{~km}$ in the early afternoon, as a consequence of topography, coastal exposure, and meteorological conditions. By using reflectance images provided by the Geostationary Operational Environmental Satellite (GOES), Planchon et al. (2006) observed the higher occurrence of SBF in the north-northeastern Brazil during the hot season of 2000 (between September and December) where the results confirmed that the SBF inland penetration varied between 40 and $100 \mathrm{~km}$ due to the higher landsea temperature difference and higher exposure to trade winds. Although most of the studies have identified the SBF successfully by using satellite images, they have been limited to a specific hour of the day - usually in the middle of the afternoon - which makes it difficult to plot the SBF behavior throughout a SBF day, which, in turn, is essential to assess its impact on meteorological conditions in any region of the world.

In this study, a combination of remote sensing (satellite images) and surface meteorological data will be used to achieve two main goals, as follows: (i) to identify and compute the SBF with statistics such as onset, cessation, duration, strength, inland penetration, and classification of SBF day and (ii) to determine the relation between the SBF and meteorological conditions in the Sergipe region.

\section{Data and methods}

\subsection{Description of the study area and dataset used}

In this paper, we study the characteristics of the SBF in the Sergipe region, located in the northeastern coast of Brazil, which is along the Atlantic coast basin between $10^{\circ} 00^{\prime} \mathrm{S}$ and $37^{\circ} 00^{\prime} \mathrm{W}$ and $11^{\circ} 00^{\prime} \mathrm{S}$ and $38^{\circ} 00^{\prime} \mathrm{W}$. The Sergipe region covers an area of 21,910 sq. $\mathrm{km}$ with about 2.288 million inhabitants (IBGE 2017). The topography of the region is relatively flat, varying between 0 and $1088 \mathrm{~m}$ above sea level (with an average altitude of about $300 \mathrm{~m}$ ), featuring a slightly curved straight coastline with $163 \mathrm{~km}$, which corresponds to $2.2 \%$ of the entire coast of Northeastern Brazil. This area is more exposed to trade winds coming from the ocean and, therefore, favoring the SBF's inland penetration (Fig. 1).

The climate in the Sergipe region is characterized by warm summers (from December to March) and mild winters (from April to July). According to Köppen's climatic classification (Alvares et al. 2013), most of the area is dominated by climate As (warm and humid tropical climate, with a dry season in the summer), but to the northwest, the climate is more severe, namely the semi-arid Bsh (low latitude and altitude) characterized by high temperatures, low humidity, and scarce and irregular rainfall regimes. Thus, the annual average temperature of the Sergipe region varies between 24 and $26^{\circ} \mathrm{C}$, relative humidity between 45 and $70 \%$, and rainfall between $520 \mathrm{~mm}$ and $1400 \mathrm{~mm}$ (INMET 2016). According to the Pereira et al. (2017), the Sergipe region is one of the areas 


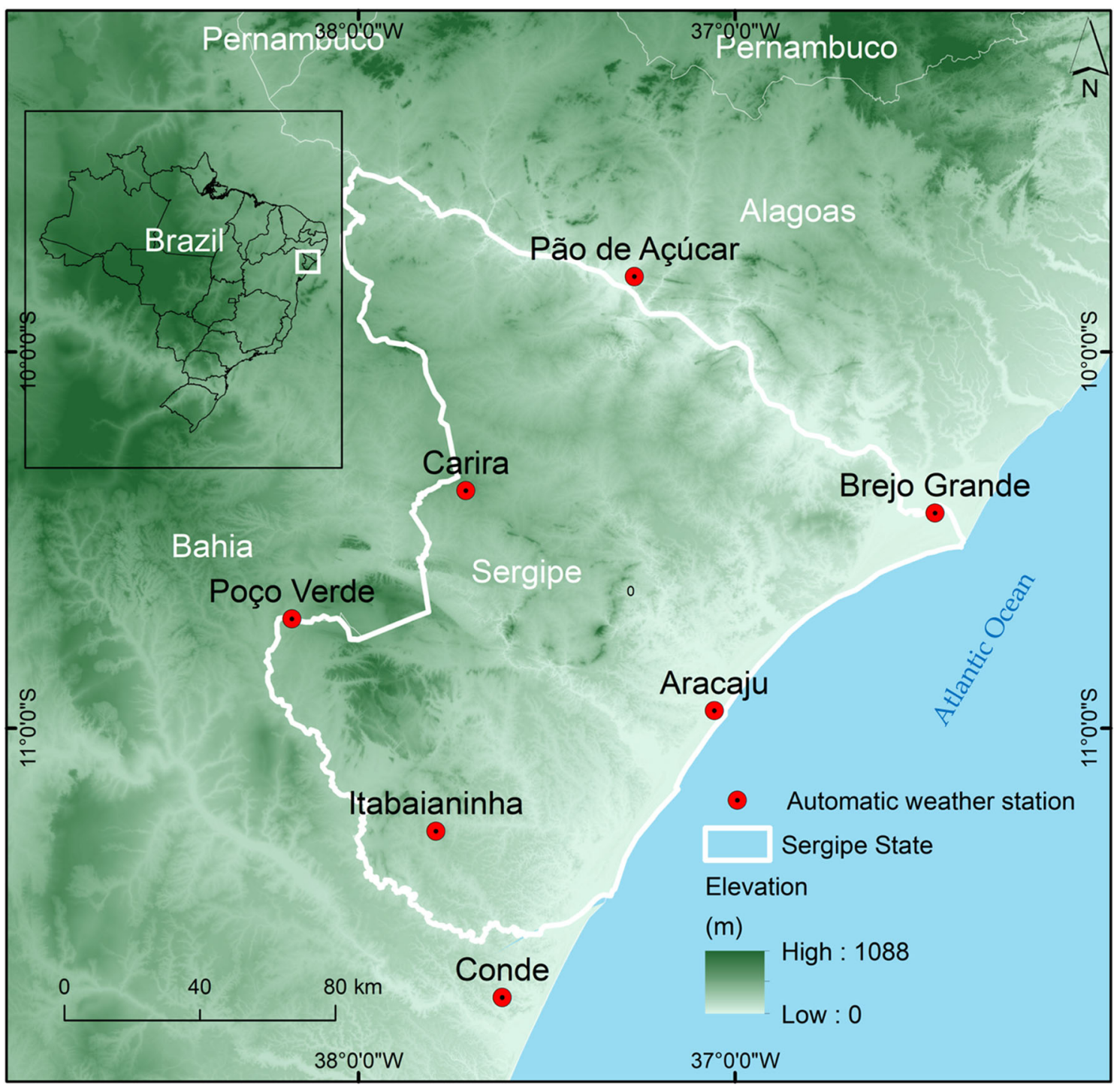

Fig. 1 Terrain map of the study area displaying the locations of automatic weather stations

with the highest solar radiation levels in Brazil with an annual average of daily global solar irradiation of $5.9 \mathrm{kWh} \mathrm{m}^{-2} \mathrm{day}^{-1}$. Furthermore, the Sergipe region is subjected to the action of several macroscale and mesoscale weather systems, such as the South Atlantic Subtropical Anticyclone (SASA), the North Atlantic Subtropical Anticyclone (NASA), and the Upper Tropospheric Cyclonic Vortices (UTCV), among others. UTCV is the system that usually occurs more strongly in the warmest months of the year, with an average lifetime varying from 4 to 11 days (Ferreira et al. 2009). UTCV symmetry (location and movement) influences the cloudiness pattern in Northeastern Brazil (Kousky and Gan 1981). Such systems and associated trade winds play an important role in understanding the Sergipe region's climate and weather.

Hourly meteorological data (wind speed, wind direction, air temperature, relative humidity, sea level pressure, solar radiation, and dew point) collected from seven surface automatic weather stations MAWS301 by Vaisala ${ }^{\circledR}$ (Helsinki, Finland) belonging to the Brazilian National Meteorological Weather Institute (INMET) were used (Table 1), covering the period between the 1st of December 2014 to the 31st of March 2015 (henceforth summer 2015). To characterize wind patterns in the Sergipe region, wind speed and direction data from 2014 to 2017 were individually analyzed. Regarding the summer period, temperature and pressure gradient differences are expected to be marked, and these are responsible for the formation and development of the SBF. To ensure a correct assessment, a quality control procedure (e.g., unreal value) was performed to validate the internal coherence in the dataset used. As surface automatic weather stations are located both on the coast and inland, we assume they reflect common wind patterns and SBF behavior in the Sergipe region. Information regarding location, topography, distances 
Table 1 Description of the automatic weather stations used in this study in the summer 2015

\begin{tabular}{lllll}
\hline Automatic weather station & Latitude & Longitude & Elevation (m) & $\begin{array}{l}\text { Distance from } \\
\text { closest sea (km) }\end{array}$ \\
\hline Aracaju & $10^{\circ} 57^{\prime} \mathrm{S}$ & $37^{\circ} 3^{\prime} \mathrm{W}$ & 4 & 3 \\
Brejo Grande & $10^{\circ} 25^{\prime} \mathrm{S}$ & $36^{\circ} 28^{\prime} \mathrm{W}$ & 6 & 11 \\
Carira & $10^{\circ} 22^{\prime} \mathrm{S}$ & $37^{\circ} 42^{\prime} \mathrm{W}$ & 290 & 99 \\
Conde & $11^{\circ} 42^{\prime} \mathrm{S}$ & $37^{\circ} 37^{\prime} \mathrm{W}$ & 5 & 11 \\
Itabaianinha & $11^{\circ} 16^{\prime} \mathrm{S}$ & $37^{\circ} 47^{\prime} \mathrm{W}$ & 205 & 54 \\
Pão de Açúcar & $9^{\circ} 48^{\prime} \mathrm{S}$ & $37^{\circ} 15^{\prime} \mathrm{W}$ & 21 & 122 \\
Poço Verde & $10^{\circ} 42^{\prime} \mathrm{S}$ & $38^{\circ} 10^{\prime} \mathrm{W}$ & 367 & 120 \\
\hline
\end{tabular}

from sea, and the time series analysis for all the weather stations is shown in Table 1.

Along with the meteorological data, remote sensing data collected by using GOES-13 satellite images on channel 4 (infrared IV) and South American surface maps (1000 hPa at 00:00 UTC) produced by the Center for Weather Forecasting and Climate Studies (CPETEC/ INPE) were used to characterize synoptic conditions during the study period. For the identification of the SBF, daytime GOES-13 images visible in channel 1 (wavelength between 0.55 and $0.75 \mu \mathrm{m}$ ) and space resolution of $1 \mathrm{~km}$ provided from CPTEC between 11:00 and 21:00 UTC for the summer 2015 were carefully analyzed. The reason for this will be discussed in the next section.

\subsection{Method to identify the SBF}

Adapted from Damato et al. (2003) and Planchon et al. (2006), the SBF identification method followed five steps, as shown in Fig. 2.

Step 1: applying satellite images In this study, 847 GOES-13 Northeastern Brazil images were sequentially analyzed to compute the SBF statistic into an environmental Geographic
Information System (GIS). The reason for us to use GOES-13 visible images is because they have well-marked differences in terms of spectral color between low-level clouds and characteristics of the land-sea surface, which allows us to identify and delineate the cloud line usually associated to the SBF. However, it is important to point out that the SBF is not always associated with the cloud line: if humidity is too low, no clouds are observed and the cloud line is not visible using the analysis of the radiometric conditions by remote sensing (Bigot and Planchon 2003). According to Planchon et al. (2006), these subjective limitations occur in conditions that are (i) synoptically disturbed with large lines of clouds not associated with SBFs and (ii) with a cloudless sky over the image used.

Step 2: identification of the cloud line and drawing the isochrone Within the SIG environment, each GOES-13 image was imported into the Feature Analyst software. This tool was especially useful for the images in which the clouds are usually not visible to the naked eye, i.e., when the conditions mentioned in item (ii) of step 1 occur. By using the "bach" function embedded in that tool, a large set of images can be processed simultaneously to export the vector that corresponds to the heap of clouds. SBFs were defined manually
STEP 1

Applying satellite images

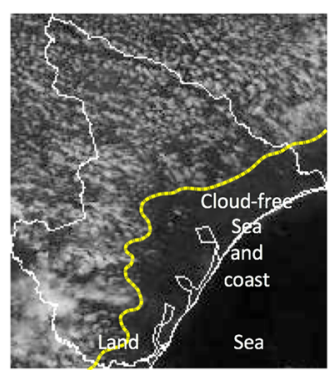

STEP 2

Identification of cloud line and drawing of the isochrone

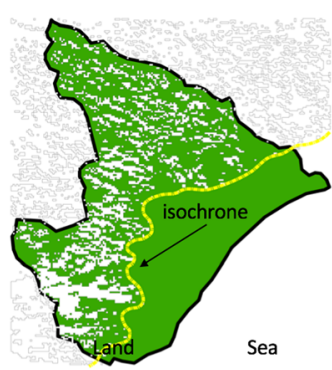

STEP 3

Georeferencing

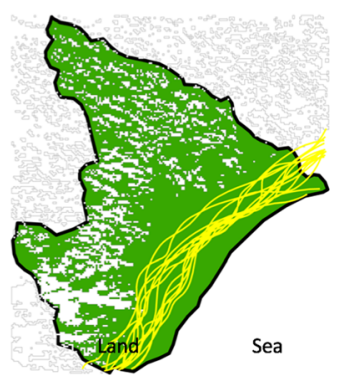

STEP 4

Line density calculation

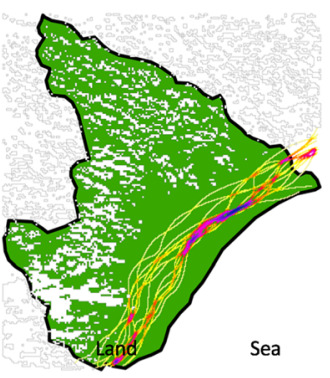

STEP 5

Definition of the hourly SBF [isochrone]

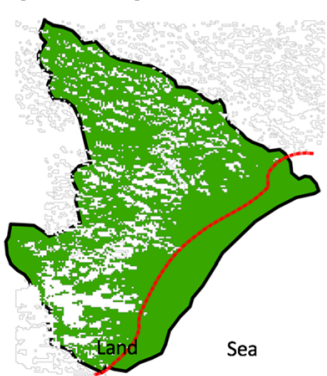

Fig. 2 Five-step method to identify the SBF using satellite imagery 
and drawn on each image (onscreen digitizing) considering the cloud line parallel to the coast, similar to what Planchon et al. (2006) used. The result was another vector format represented by an isochrone.

Step 3: georeferencing This step is an essential condition for a spatialization of the SBF on the map to measure its inland penetration properly. Here, every vector file created in step 2 was georeferenced in the coordinate system (South American Datum/Zone 24 and Transverse Mercator projection), and then plotted on a map of the Sergipe region, and subsequently converted into grid format.

Step 4: line density calculation To calculate the line density with a high frequency of the SBF passage in an area, the kernel density estimates algorithm was used (Bailey and Gatrell 1995). The process of drawing over each raster (step 2) was repeated to create a smooth vector which would correspond to the specific mean hourly of the SBF passage.

Step 5: definition of the hourly SBF The final vector file was considered as an isochrone that represents SBF passage in a specific hour of the day.

\subsection{Formulation of a climatology of the SBF}

After the identification of the SBF events, the statistics were computed as follows:

I. Onset (unit-hour): defined as the time during which a cloud line is observed in the image over the continent. The onset of the SBF was considered when the wind direction was from $30^{\circ}$ to $150^{\circ}$.
II. Cessation (hour): defined as the time during which the cloud line disappears in the image, usually far from the coastline and close to sunset

III. Duration (hour): period of time defined between onset and cessation

IV. Strength $\left(\mathrm{ms}^{-1}\right)$ : defined as the magnitude of the horizontal advance of the SBF expressed by mean wind speed. To calculate the strength of the SBF, wind speed data at the exact moment of the SBF passage were computed. The spatialization of the SBF on a map helps to identify which weather stations should be included in the calculation of strength. The consecutive introduction of the wind speed data to compute the strength of the SBF takes into account the fact that it advances inland in one predominant direction as defined at the onset stage.

V. Inland penetration $(\mathrm{km})$ : maximum extension of the SBF inland based on an observational line through the inland projected from the coast of Aracaju

VI. Classification of a SBF day: the first task was to eliminate the synoptic events that did not allow the identification of the cloud line associated with the SBF on the satellite image. Secondly, a good example of a SBF day from the GOES-13 image is seen in Fig. 3a, which shows the visible presence of SBF by greater cloud development along a line. The well-delimited cloud-free zone is seen on the seaward side of this line, meaning a common potential signature of the sea breeze (Planchon et al. 2006; Simpson 1994). Since the synoptic systems of that region last several hours of the day until the night, we assumed that the situation was likely to be a SBF day. A SBF day considered once the onset and cessation stages were reached. On the other
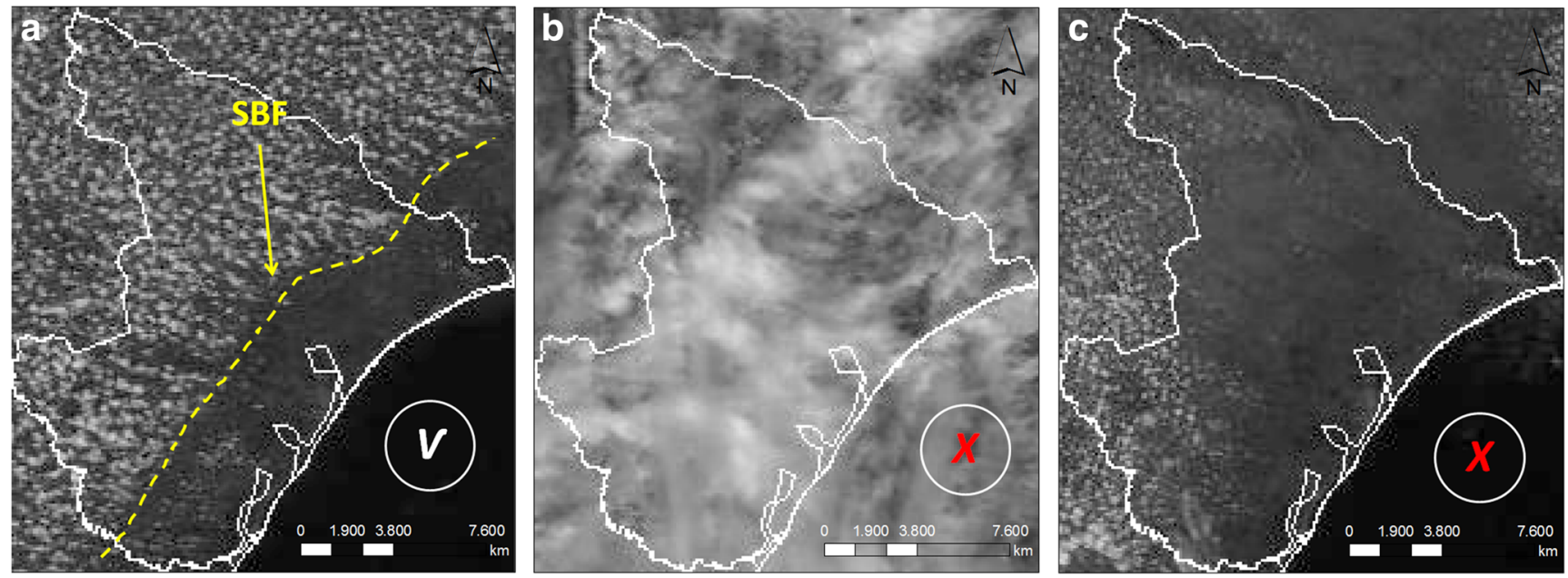

Fig. 3 Examples of three Sergipe region GOES-13 images at 16:00 UTC on different days. a SBF associated with a line of cumulus on January 3 , 2015. b Synoptically disturbed conditions and wide clouds not associated with the SBF on December 15, 2014. c Cloudless skies over the whole study area not associated with the SBF on March 28, 2015 

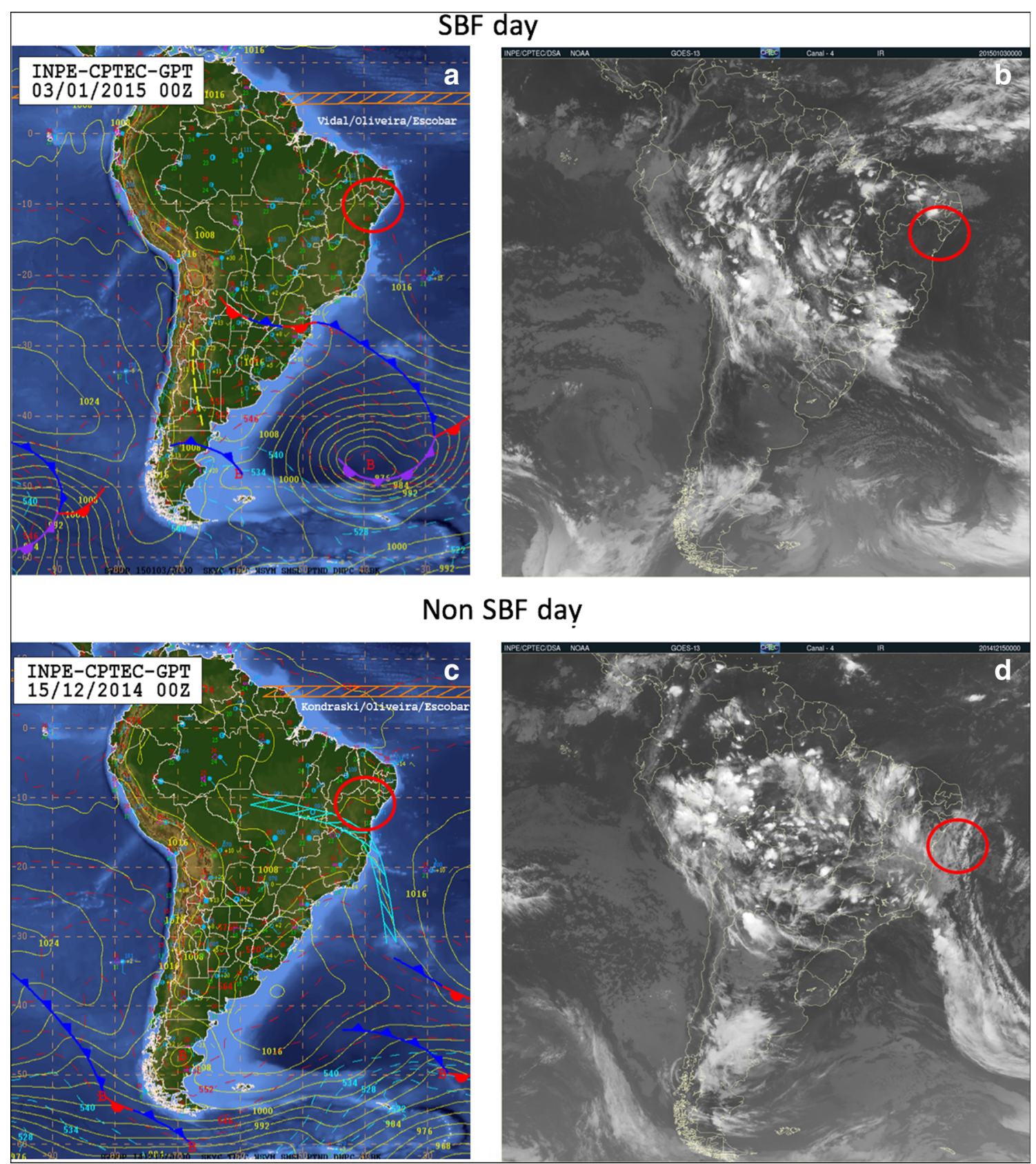

Fig. 4 South American surface maps at sea level pressure- hectopascals (a, c) and GOES-13 images on channel 4 (infrared IV) (b, d) by CPETEC/INPE both at 00:00 UTC during a SBF day (January 3, 2015) and a non-SBF day (December 15, 2014)

hand, Fig. $3 \mathrm{~b}$ shows an example of the action of a synoptic system on the GOES13 image whose high concentration and discontinuity of cumulus clouds are visible at a specific hour of the day and Fig. $3 \mathrm{c}$ shows a clear sky without clouds on the GOES13 image. These situations were rejected as possible SBF days in this study area.

Subsequently, several statistical analyses and assessments of the SBF were made as follows:
I. Statistical evaluation of the number of daily and monthly occurrence

II. Definition of the daily cycle using onset, cessation, duration, and strength

III. Spatio-temporal frequency of the hourly and monthly passage

IV. Computation of hourly and monthly inland penetration

V. Comparison between SBF days and non-SBF days

Finally, we explored the relationship between the SBF and meteorological conditions in the Sergipe region by comparing 


\section{Aracaju}

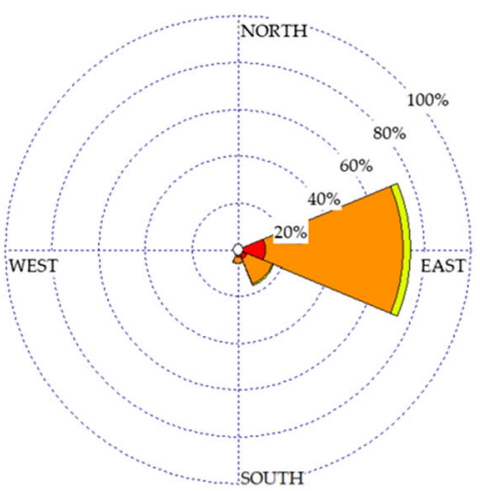

Itabaianinha

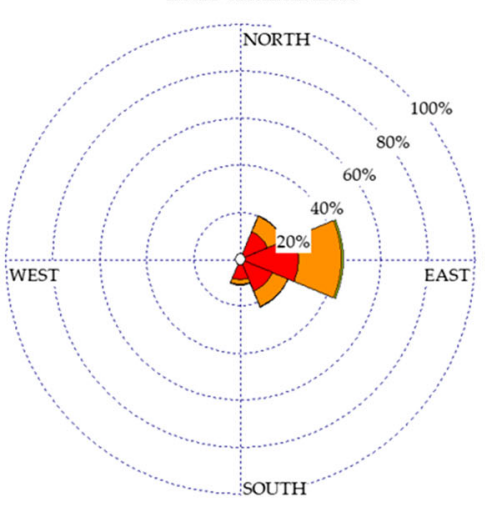

Brejo Grande

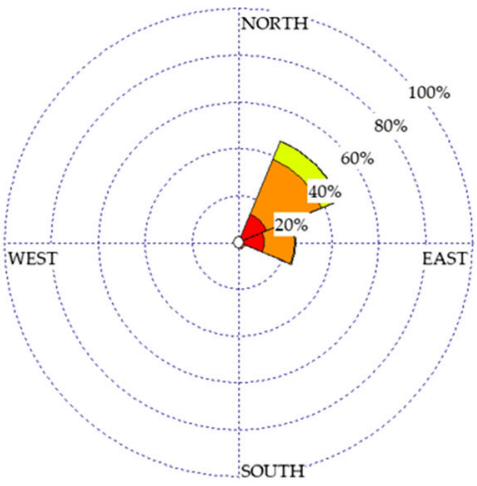

Pão de Açúcar

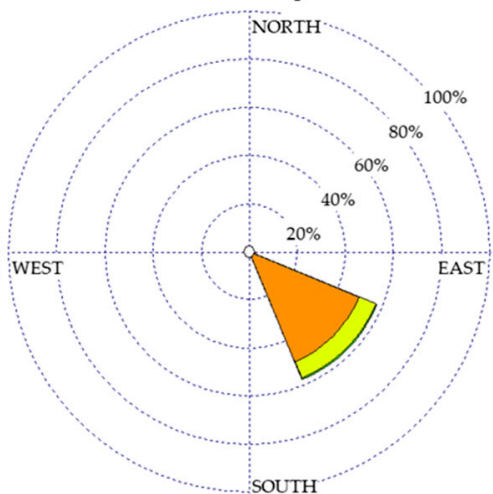

Conde

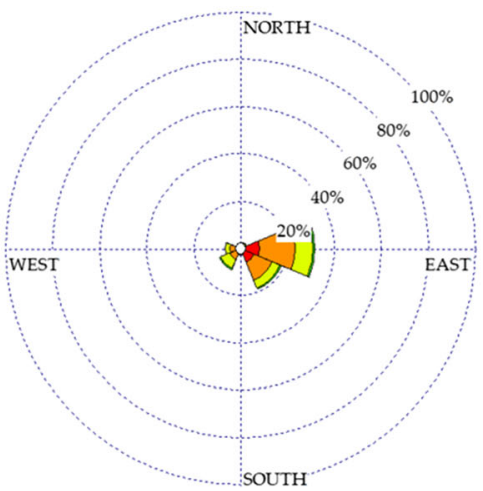

Carira

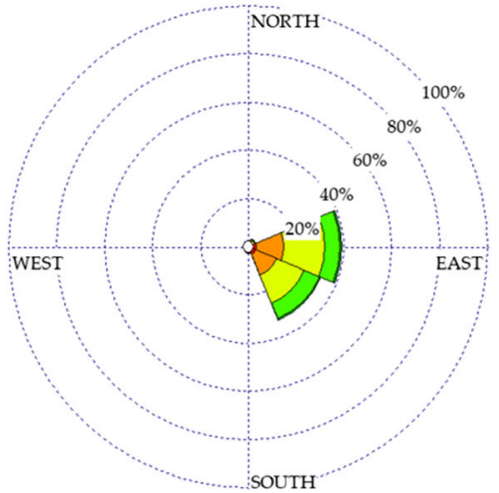

Poço Verde

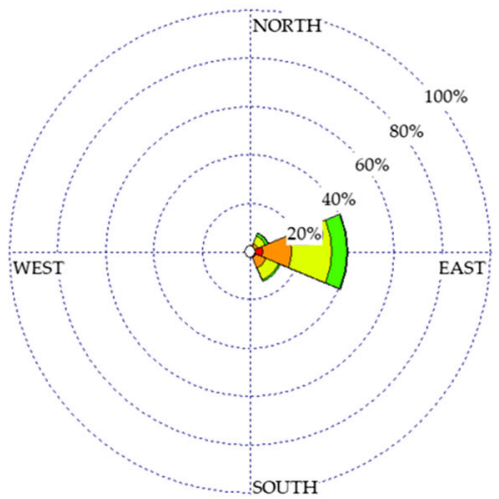

Wind Speed

$\left(\mathrm{m} \mathrm{s}^{-1}\right)$

$\square>=10$

$8-10$

6-8

$\square$ 4-6

$2-4$

$0,5-2$

Fig. 5 Wind roses showing direction and speed frequencies with eight categories for seven weather stations in the Sergipe region in the 2010-2017 period

the hourly mean of seven meteorological variables (wind speed, wind direction, temperature, relative humidity, sea level pressure, solar radiation, and dew point temperature) during SBF days and non-SBF days in the summer 2015 period.
Table 2 Statistics of SBF

occurrence in the summer 2015

\begin{tabular}{lllll}
\hline Month-year & $\begin{array}{l}\text { No. of } \\
\text { SBF days }\end{array}$ & $\begin{array}{l}\text { No. of } \\
\text { non-SBF days }\end{array}$ & $\begin{array}{l}\text { No. of days } \\
\text { analyzed }\end{array}$ & $\begin{array}{l}\text { No. of GOES-13 } \\
\text { images analyzed }\end{array}$ \\
\hline December-2014 & 16 & 15 & 31 & 217 \\
January-2015 & 17 & 14 & 31 & 217 \\
February-2015 & 16 & 12 & 28 & 196 \\
March-2015 & 18 & 13 & 31 & 217 \\
Summary & 67 & 54 & 121 & 847 \\
\hline
\end{tabular}


Fig. 6 Number of hourly occurrences, strength (wind speed $-\mathrm{ms}^{-1}$ ), onset, duration and cessation (hour) of the SBF in the summer 2015

\section{Results}

\subsection{Synoptic setting}

The synoptic analysis for this study period shows, on the surface level, that SASA is located over Southeastern Atlantic Ocean (Fig. 4a, c) and a UTCV is positioned over the northeastern portion of Brazil during a SBF day and a nonSBF day (Fig. 4b, d). The position and movement of the SASA and UTCV have a pronounced effect on the meteorological conditions over the South American continent. Figure $4 \mathrm{~b}$ shows, on January 3, 2015, an atmospheric stability characterized by clear sky due to the position of the vortex center of UTCV over of the study area, which favors cloudiness associated with the SBF. Figure $4 d$ shows, on December 15, 2014, an atmospheric instability with strong convective activity because of the movement of the UTCV over the Sergipe region, which did not favor the typical cloudiness of the SBF.

\subsection{Wind pattern characterization}

Figure 5 shows the eastern prevailing wind direction at almost all the weather stations, except Brejo Grande with the wind blowing from northeast and Pão de Açúcar with southeastern winds. The mean wind speed frequencies between the weather stations were differentiated due to topography and distance from coast: the highest wind speed is 2 to $4 \mathrm{~ms}^{-1}$ highlighting the Aracaju station with $75 \%$ of frequencies, followed by Pão de Açúcar station with $51 \%$, Itabaianinha with $48 \%$, Brejo Grande with $40 \%$, and Conde with $20 \%$. For the inland stations, the highest frequencies of $35 \%$ in the strong wind class of $4-6 \mathrm{~ms}^{-1}$ and about $10 \%$ in the class 6-8 $\mathrm{ms}^{-1}$ were recorded in Poço Verde and Carira. These stations also registered $20 \%$ of frequencies in the light wind class of up to $0.5 \mathrm{~ms}^{-1}$.

\subsection{Characterization of the SBF}

\subsubsection{Daily cycle and occurrence}

Table 2 shows that from 121 summer days analyzed (total of 847 GOES-13 images), 67 days were computed as SBF days and 54 as non-SBF days. March had the highest number of days with SBF (18), followed by January (17), February, and December both with 16 days.

Figure 6 presents the hourly number of occurrence and strength of the SBF in the summer 2015, where the onset of the SBF started at 12:00 UTC with 5 occurrences and the cessation occurred at 19:00 UTC with 47 occurrences, which leads to the duration of $7 \mathrm{~h}$ with the maximum of occurrence (60) of the SBF at 16:00 UTC. In the daily cycle period, the hourly mean strength of the SBF was $3.7 \mathrm{~ms}^{-1}$, varying between the minimum of $3.3 \mathrm{~ms}^{-1}$ at 12:00 UTC and the maximum of $4.0 \mathrm{~ms}^{-1}$ at 19:00 UTC.

\subsubsection{Spatio-temporal organization}

The spatio-temporal of the SBF inlands represented by the isochrones was plotted on the Sergipe region map for each month of the study period. As seen in Fig. 7, the SBF was relatively uniform during the summer months with the maximum advance of the isochrones inland occurring in March (at 19:00 UTC) (Fig. 7d). Figure 8 also shows mean hourly SBF passage summarized for the summer months 2015, in which the SBF passage was not observed in certain municipalities of the Sergipe region: Poço Verde (southwest), Nossa Senhora da Glória, Poço Redondo, and Canindé do São Francisco (north-northwestern).

\subsubsection{Inland penetration}

The hourly inland advance of the SBF on several municipalities of the Sergipe region was calculated (Table 3). As expected, there was a gradual increase of the mean advance of the SBF throughout the day and months varying between the 

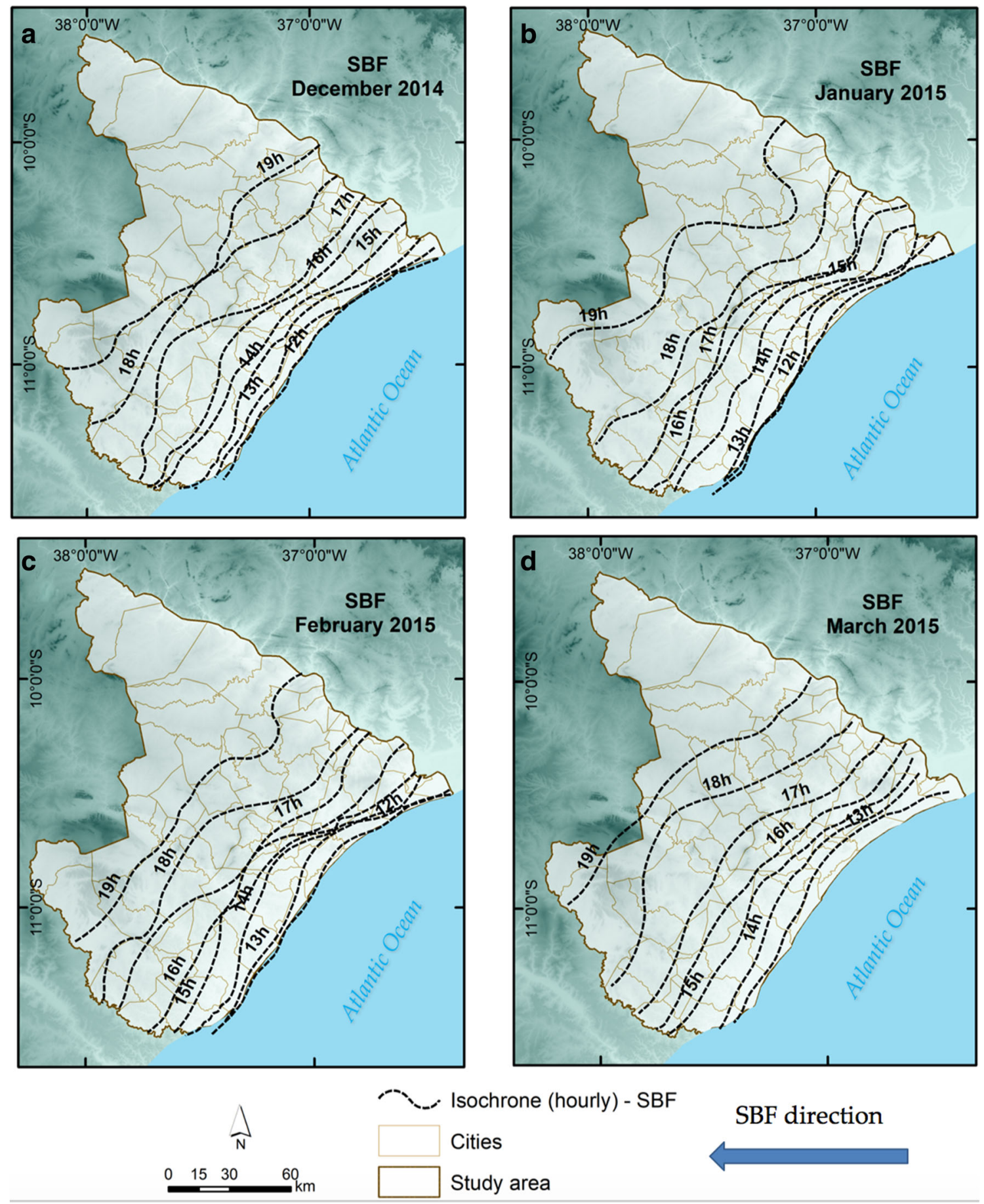

\section{SBF direction}

\section{Study area}

Fig. 7 Mean-hourly month isochrones of the SBF in the Sergipe region for the summer months 2015. a December 2014. b January. c February. d March 2015. The dashed curved lines indicate the SBF

maximum distance of $94 \mathrm{~km}$ at 19:00 UTC in March and the minimum distance of $0.5 \mathrm{~km}$ at 12:00 UTC in December from coast during an SBF occurrence.

Regarding the isochronous advance in March, at 13:00 UTC, the SBF was restricted near coast on the municipalities of Aracaju and Barra dos Coqueiros (Fig. 9). Later, at 16:00 UTC, the SBF was observed on the municipalities of
Laranjeiras and Itaporanga D'Ajuda located $30 \mathrm{~km}$ away, which represents a mean advance inland of $10 \mathrm{~km}$ per hour. This inland advance doubled $(20 \mathrm{~km})$ with the arrival of the SBF at 17:00 UTC to the municipalities of Areia Branca and Itabaianinha located $43 \mathrm{~km}$ from coast. By 19:00 UTC, the longest penetration inland of the SBF was registered on the municipalities of Carira and Pinhão located $94 \mathrm{~km}$ away from the coast. 


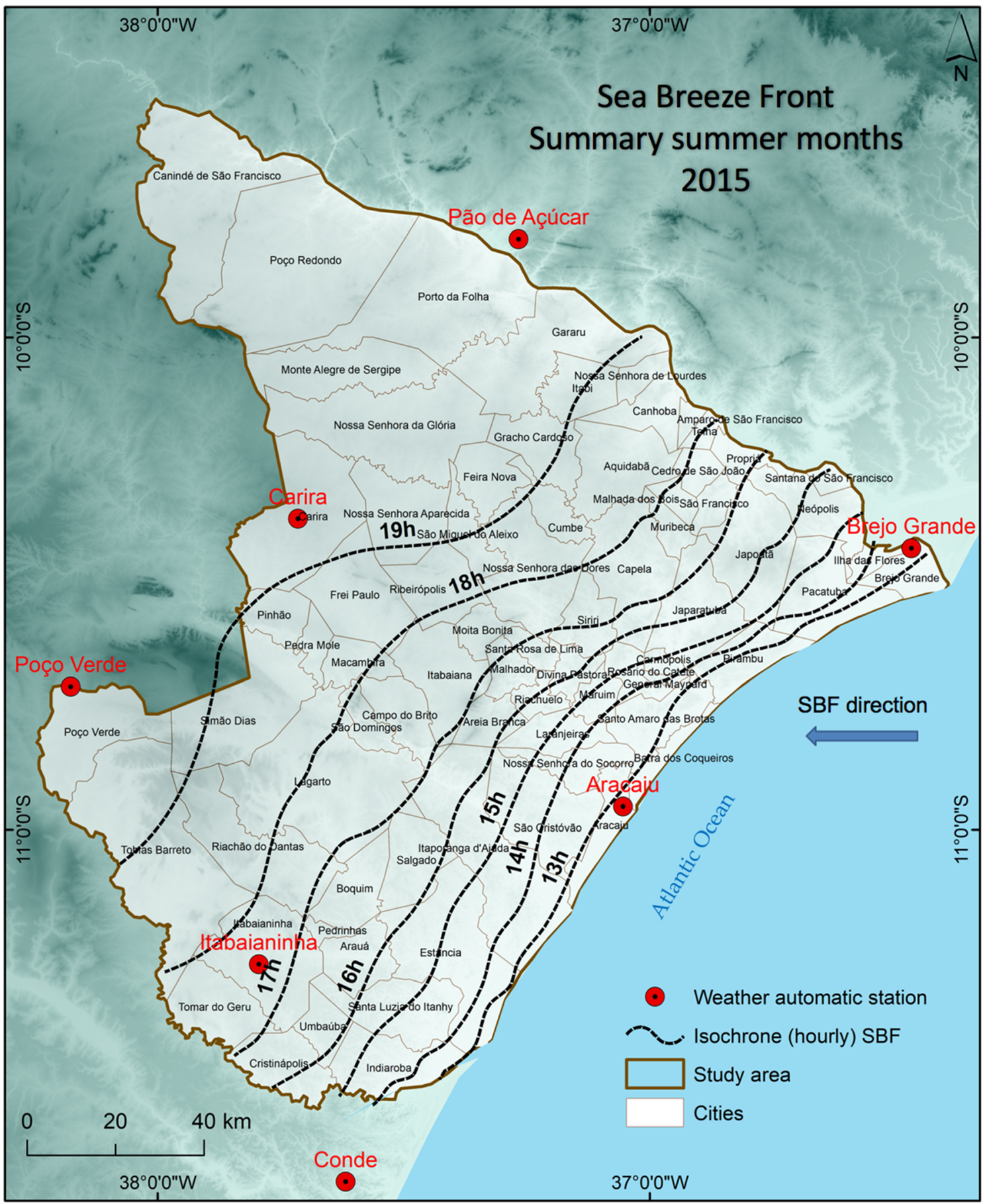

Fig. 8 Summary of the mean-hourly isochrones of the SBF in the Sergipe region for the summer months 2015 (betwenn December 2014 and March 2015). The dashed curved lines indicate the SBF

\subsection{Relationship between the SBF and meteorological conditions}

The daytime hourly mean set of meteorological variables for SBF days and non-SBF days in the summer 2015 is presented in Fig. 10. The mean sea level pressure remained almost constant during SBF days and non-SBF days (Fig. 10 (A)). Daytime wind speed difference is almost unnoticeable for
SBF days and non-SBF days varying between $1.5 \mathrm{~ms}^{-1}$ at 10:00 UTC and $4 \mathrm{~ms}^{-1}$ at 19:00 UTC (Fig. 10 (B)). The mean solar radiation increased during SBF days reaching $861 \mathrm{~W} \mathrm{~m}^{-2}$ at 16:00 UTC that compares with non-SBF days that reached around $777 \mathrm{~W} \mathrm{~m}^{-2}$, i.e., a $84 \mathrm{~W} \mathrm{~m}^{-2}$ difference (Fig. $10(\mathrm{C})$ ). As a consequence, the mean temperature difference of up to $1^{\circ} \mathrm{C}$ was particularly noticeable during a SBF day from 12:00 to 19:00 UTC (duration stage) when 
Table 3 Inland penetration of the SBF (hourly) in the summer 2015

\begin{tabular}{|c|c|c|c|c|c|c|c|c|c|c|c|c|c|c|c|c|}
\hline \multirow[t]{3}{*}{ Month-year } & \multicolumn{16}{|c|}{ Hour (UTC) } \\
\hline & \multicolumn{2}{|c|}{$12: 00$} & \multicolumn{2}{|c|}{ 13:00 } & \multicolumn{2}{|c|}{$14: 00$} & \multicolumn{2}{|c|}{$15: 00$} & \multicolumn{2}{|c|}{$16: 00$} & \multicolumn{2}{|c|}{$17: 00$} & \multicolumn{2}{|c|}{ 18:00 } & \multicolumn{2}{|c|}{ 19:00 } \\
\hline & \multicolumn{16}{|c|}{ Distance to coast during SBF occurrence $(\mathrm{km})$ and (standard deviation) } \\
\hline December-2014 & 0.5 & $(0.13)$ & 7 & $(1.78)$ & 15 & $(1.7)$ & 18 & $(6.02)$ & 32 & $(1.28)$ & 48 & $(3.5)$ & 62 & $(2.52)$ & 72 & $(10.94)$ \\
\hline January-2015 & 0.7 & $(0.07)$ & 3 & $(2.52)$ & 14 & (2.7) & 24 & $(0.58)$ & 36 & $(2.72)$ & 43 & $(1.5)$ & 50 & $(14.52)$ & 80 & $(2.94)$ \\
\hline February-2015 & 0.7 & $(0.07)$ & 4 & $(0.82)$ & 20 & (3.3) & 25 & $(0.98)$ & 31 & $(2.28)$ & 38 & $(6.5)$ & 61 & $(3.52)$ & 73 & $(9.94)$ \\
\hline March-2015 & - & & 6 & $(0.78)$ & 17 & $(0.8)$ & 27 & $(3.48)$ & 33 & $(0.12)$ & 50 & (6) & 82 & (18.08) & 94 & $(10.76)$ \\
\hline Summary of the months & - & & 6 & $(0.78)$ & 17 & $(0.3)$ & 21 & $(0.98)$ & 33 & $(0.72)$ & 43 & $(1.5)$ & 57 & $(2.48)$ & 75 & (13.06) \\
\hline
\end{tabular}

compared to non-SBF days (Fig. 10 (D)). In this interval of time, the relative humidity decreased only a little on SBF-days until nighttime (Fig. 10 (E)) and the mean dew point temperature decreased by $1{ }^{\circ} \mathrm{C}$ more on SBF days than non-SBF days (Fig. $10(\mathrm{~F})$ ).

\section{Discussion}

The Sergipe region has relatively low topography and an almost straight coastline, making it more exposed to trade winds coming from the sea, which forces the inland penetration of the sea breeze. Thus, this study presented the first evidences of the daily variations of the SBF. Remote sensing using the GOES-13 satellite images combined with meteorological data has proved to be a powerful method to identify the SBF and to analyze its implications on meteorological conditions in the Sergipe region, which may serve as a reference for other coastal regions. Based on this method, the first climatology of the SBF of the northeastern coast of Brazil was presented, including daily behavior.

Results have shown that the SBF in the Sergipe region acts between 12:00 and 19:00 UTC (09:00 to 16:00 local time), which fluctuates from $\sim 03: 00 \mathrm{~h}$ after sunrise to $\sim$ 2:00 $\mathrm{h}$ before sunset. This is consistent with Yamato et al.'s (2017) study on the Tokyo Metropolitan area that observed the SBF between 12:00 and 16:00 (local time) and with Azorin-Molina and Chen's (2009) study in Alicante (Spain), in which they found that the mean onset of the sea breeze occurred at 09:40 UTC and cessation at 20:00 UTC. In addition, the SBF typically has a duration of $6 \mathrm{~h}$ with prevailing eastern and southeastern winds and the mean strength of $3.6 \mathrm{~ms}^{-1}$, reaching a maximum of $4.0 \mathrm{~ms}^{-1}$ close to cessation. The SBF advance inland, on average, from 10 to $20 \mathrm{~km}$ every hour, with the highest inland penetration of $94 \mathrm{~km}$ from the coast. Simpson (1994) and Simpson et al. (1977) reported that the magnitude of the wind component associated with the coastal environment is an important force for inland penetration of the SBF. This has also been observed in the Sergipe region, where the mean maximum strength of the SBF of $4.0 \mathrm{~ms}^{-1}$ coincided with the rising trade winds speed in daytime as illustrated by Fig. 10 (B), once the higher inland penetration (94 km) occurred at sunset (at 19:00 UTC). This result is in accordance with Planchon et al.'s (2006) study, in which the inland SBF penetrated $100 \mathrm{~km}$ (at 18:00 UTC) in the north-northeast region of Brazil as well as with the Simpson et al.'s (1977) and Damato et al.'s (2003) studies that registered SBF advance inland between 17 and $34 \mathrm{~km}$ in the early afternoon.

These findings reinforce the fact that the sea breeze in the Sergipe region is influenced by the synoptic flow and weather systems, particularly trade winds. As reported by VerejãoSilva (2001) and Barreto et al. (2002), in this study, the SBF presence did not cause significant changes in wind speed and direction (Figs. 5 and 10 (B)) due to the persistence of trade winds throughout the day and year. Furthermore, the SBF is sensitive to the variations of the synoptic mesoscale systems, such as SASA and UTCV, which favors cloud pattern that helps to identify the cloud line associated with the SBF on the GOES-13 image. Sea level pressure analysis in the Fig. 10 (A) clearly indicated on the Sergipe region a reasonably low variability in wind direction and speed during the SBF days and non-SBF days.

In this study, the most interesting finding was the fact that the SBF passage is related with warmer days in the Sergipe region. We hypothesize that after the SBF has passaged (after the cloud line movement), clear sky conditions were created that allowed for the entrance of more direct solar radiation to the low-level atmosphere; this available energy is converted into sensible heat flow and stored in the ground eventually increasing surface and air temperatures and resulting in warmer days. In this study, the day is considered to be warmer when the mean solar radiation and air temperature values that day have increased due to the SBF development. Thus, there was a mean increase by $84 \mathrm{~W} \mathrm{~m}^{-2}$ of solar radiation and $1{ }^{\circ} \mathrm{C}$ of 
Fig. 9 Summary of isochrones of inland penetration of the SBF (hourly) in the summer 2015. Also displayed is a straight dashed line representing the observation on the Sergipe region and dashed curved lines indicating the SBF

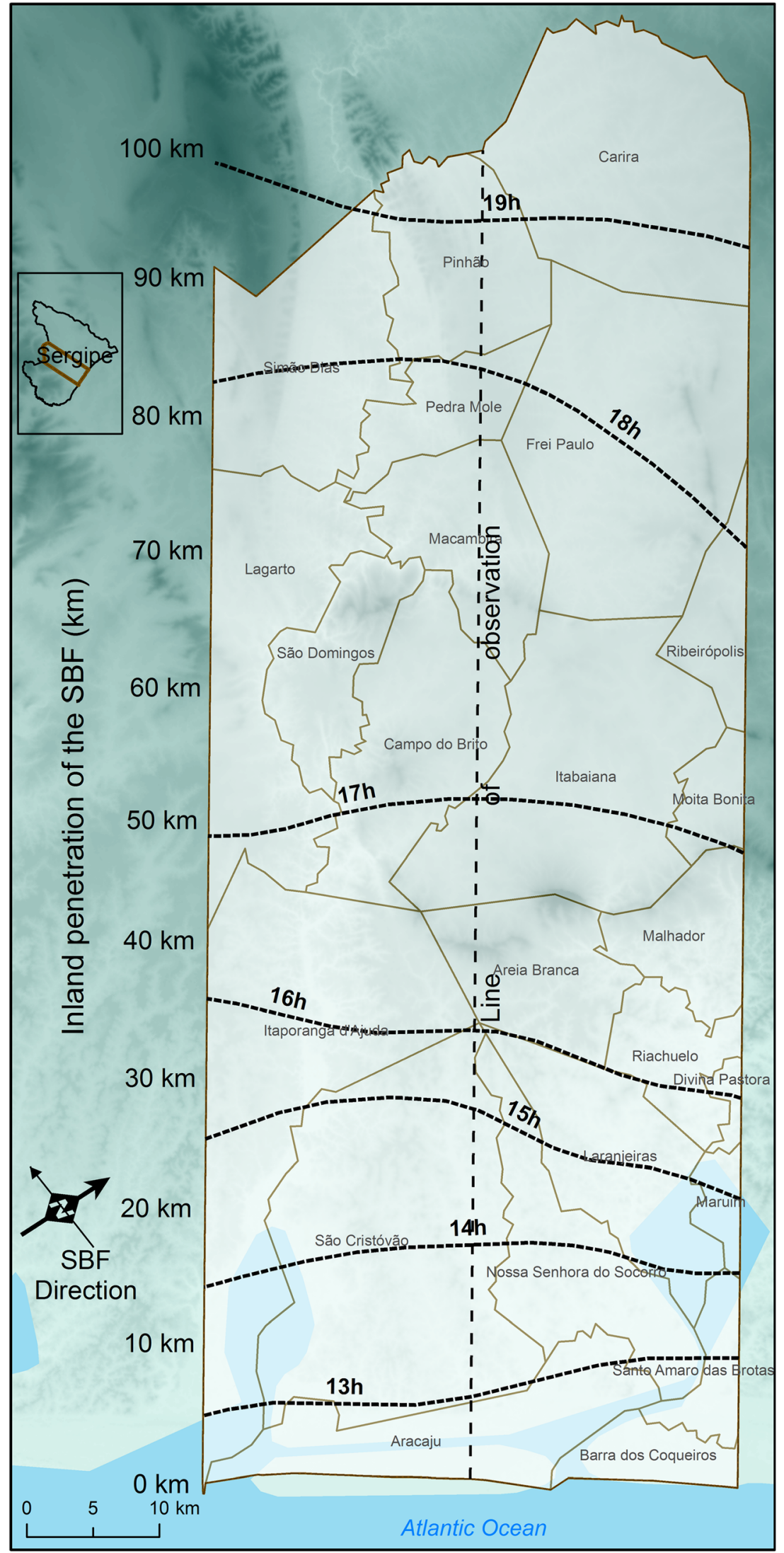



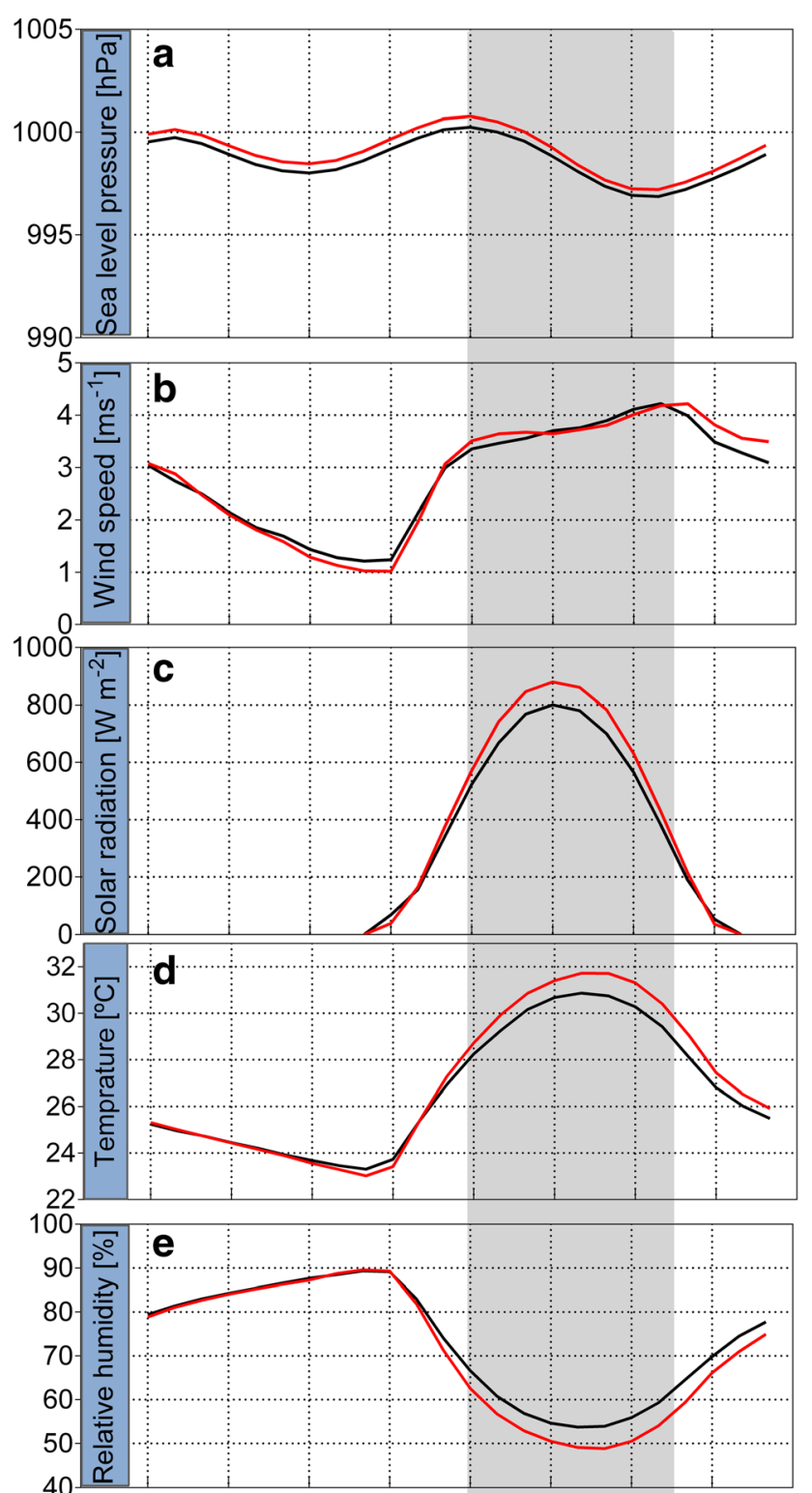

40

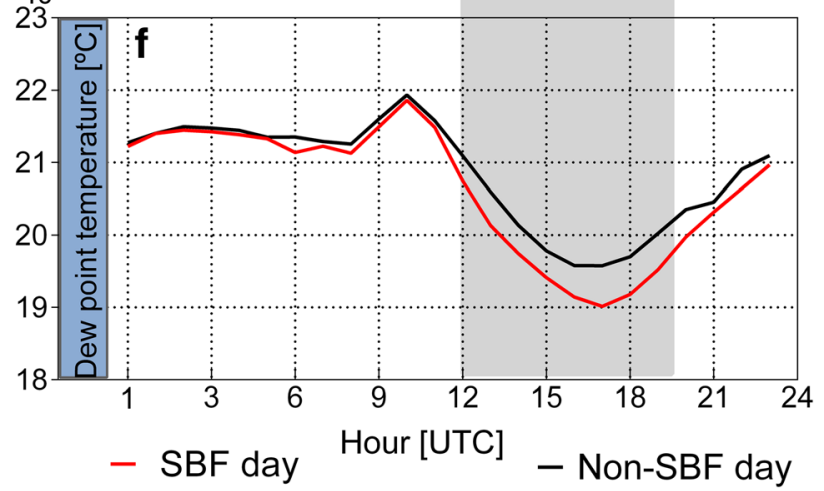

Fig. 10 Daytime hourly mean of all weather station of (A) sea level pressure, (B) wind speed and direction, (C) solar radiation, (D) air temperature, (E) relative humidity, and (F) dew point temperature for SBF days and non-SBF days in the summer 2015. Also displayed is the duration of the SBF from 12:00 to 19:00 (hatched grey area) temperature during SBF days when compared with nonSBF days as shown in Fig. 10 (C, D). These results are in agreement with those found by Khan (2010) in the region of Auckland, where he showed a $1.5{ }^{\circ} \mathrm{C}$ rise in mean temperature followed by the mean positive difference of total daily solar flux of up to $0.83 \mathrm{kWh} \mathrm{m}^{-2}$ day $^{-1}$ during sea breeze days. Relative humidity levels did not show a significant difference between SBF days and non-SBF days. First, the cool air from the sea (onshore) is expected to raise humidity levels in the Sergipe region; however, due to the coastal location of the region and the regular trade winds, a humidity rise during breeze events is unexpected. Second, contrary to expectations, the little decrease by $10 \%$ verified during SBF days is caused by the increase of temperature at this moment. In response to the temperature increase and relative humidity decrease, the dew point temperature began to decrease during the SBF passage as seen in Fig. 10 (F). Results suggest that there was not an increase in water vapor (or absolute humidity) with the SBF passage, which disagrees with the observations made by Sánchez-Ccoyllo and Silva Dias (2000) in São Paulo.

The findings reported in this study contradict the common idea that the sea breeze is always a beneficial phenomenon from the thermal point of view. The idea that the inhabitants of coastal settlements often find the cool sea breeze to be beneficial in offsetting a hot climate (Oke 1987) seems to be more complex, regarding the sea breeze development on the northeastern coast of Brazil. In fact, since the SBF implies an increase in temperature and solar radiation and results in warmer days, it can decrease human thermal comfort in the urban areas of the Sergipe region.

\section{Conclusion}

The sea breeze, here represented as the SBF, is an important mesoscale system in the Sergipe region due to its frequency and intensity. By using remote sensing (GOES-13 satellite images) and surface meteorological data, the first climatology of the SBF for the northeastern coast of Brazil that includes daily behavior (onset, cessation, duration, inland penetration, classification by SBF day) was presented. Based on this climatology, it was possible to evaluate a relationship between the SBF and meteorological conditions in the Sergipe region, which showed warmer days related to the SBF passage as a function of the mean increase of solar radiation $\left(84 \mathrm{~W} \mathrm{~m}^{-2}\right)$ and temperature $\left(1{ }^{\circ} \mathrm{C}\right)$ verified. This 
suggests that the SBF can be an aggravating factor for human thermal comfort in the Sergipe region, which is regarded as a naturally "stressful" thermal environment.

Acknowledgments We hereby thank to the anonymous reviewers for their very constructive and useful comments.

Funding information This research was funded by the CAPESFoundation, Ministry of Education of Brazil, Brasília DF 70040-020, Brazil.

Open Access This article is distributed under the terms of the Creative Commons Attribution 4.0 International License (http:// creativecommons.org/licenses/by/4.0/), which permits unrestricted use, distribution, and reproduction in any medium, provided you give appropriate credit to the original author(s) and the source, provide a link to the Creative Commons license, and indicate if changes were made.

Publisher's note Springer Nature remains neutral with regard to jurisdictional claims in published maps and institutional affiliations.

\section{References}

Acero JA, Arrizabalaga J, Kupski S, Katzschner L (2013) Urban heat island in a coastal urban area in northern Spain. Theor Appl Climatol 113:137-154. https://doi.org/10.1007/s00704-012-0774-Z

Alvares CA, Stape JL, Sentelhas PC, Moraes Gonçalves JL, Sparovek G (2013) Köppen's climate classification map for Brazil. Meteorol Z 22:711-728. https://doi.org/10.1127/0941-2948/2013/0507

Atkinson B (1981) Meso-scale atmospheric circulations. Academic, London

Azorin-Molina C, Chen D (2009) A climatological study of the influence of synoptic-scale flows on sea breeze evolution in the Bay of Alicante (Spain). Theor Appl Climatol 96:249-260. https://doi.org/ 10.1007/s00704-008-0028-2

Azorin-Molina C, Chen D, Tijm S, Baldi M (2011) A multi-year study of sea breezes in a Mediterranean coastal site: Alicante (Spain). Int J Climatol 31:468-486. https://doi.org/10.1002/joc.2064

Bailey TC, Gatrell AC (1995) Interactive spatial data analysis. Longman, Essex

Banta RM, Olivier LD, Levinson DH (1993) Evolution of the Monterey Bay sea-breeze layer as observed by Pulsed Doppler Lidar. J Atmos Sci 50:3959-3982. https://doi.org/10.1175/1520-0469(1993) 050<3959:EOTMBS>2.0.CO;2

Barreto AB, Aragão MRS, Braga CC (2002) Study of the daily cycle of low-level wind for the Northeastern of Brazil. In: XII Brazilian Congress of Meteorology. Foz de Iguaçu, pp 469-479 (In Portuguese)

Bhate J, Kesarkar AP, Karipot A, Subrahamanyam DB, Rajasekhar M, Sathiyamoorthy V, Kishtawal CM (2016) A sea breeze induced thunderstorm over an inland station over Indian South Peninsulaa case study. J Atmos Sol Terr Phys 148:96-111. https://doi.org/10. 1016/j.jastp.2016.09.002

Bigot S, Planchon O (2003) Identification and characterization of sea breeze days in northern France using singular value decomposition. Int J Climatol 23:1397-1405. https://doi.org/10.1002/joc.940

Cautenet S, Rosset R (1989) Numerical simulation of sea breezes with vertical wind shear during dry season at Cape of Three Points, West Africa. Mon Weather Rev 117:329-339

Clappier A, Martilli A, Grossi P, Thunis P, Pasi F, Krueger BC, Calpini B, Graziani G, Bergh H (2000) Effect of sea breeze on air pollution in the Greater Athens area. Part I: Numerical Simulations and Field Observations. J Appl Meteorol 39:546-562. https://doi.org/10. 1175/1520-0450(2000)039<0546:EOSBOA >2.0.CO;2

Crosman ET, Horel JD (2010) Sea and lake breezes: a review of numerical studies. Bound-Layer Meteorol 137:1-29. https://doi.org/10. 1007/s10546-010-9517-9

Damato F, Planchon O, Dubreuil V (2003) A remote-sensing study of the inland penetration of sea-breeze fronts from the English Channel. Weather 58:219-226. https://doi.org/10.1256/wea.50.02

Dandou A, Tombrou M, Soulakellis N (2009) The influence of the City of Athens on the evolution of the sea-breeze front. Bound-Layer Meteorol 131:35-51. https://doi.org/10.1007/s10546-008-9306-x

Emmanuel R, Johansson E (2006) Influence of urban morphology and sea breeze on hot humid microclimate: the case of Colombo, Sri Lanka. Clim Res 30:189-200. https://doi.org/10.3354/cr030189

Ferreira NJ, Ramirez MV, Gan MA (2009) Upper tropospheric cyclonic vortices in the Northeastern of Brazil surrounds. In: Cavalcanti IFA, Ferreira NJ, Silva MGAJ, Silva Dias MAF (eds) Weather and climate in Brazil. Oficina de textos, São Paulo (In Portuguese)

Franchito SH, Rao VB, Stech JL, Lorenzzetti JA (1998) The effect of coastal upwelling on the sea-breeze circulation at Cabo Frio, Brazil: a numerical experiment. Ann Geophys 16:866-871. https://doi.org/ 10.1007/s00585-998-0866-3

Freitas ED, Rozoff CM, Cotton WR, Dias PLS (2006) Interactions of an urban heat island and sea-breeze circulations during winter over the metropolitan area of São Paulo, Brazil. Bound-Layer Meteorol 122: 43-65. https://doi.org/10.1007/s10546-006-9091-3

Freitas ED, Silva Dias PL, Carvalho VSB, Rocha CRM, Martins LD, Martins JA, Andrade MF (2009) Factors involved in the formation and development of severe weather conditions over the megacity of São Paulo. Eighth Symposium on the Urban Environment, Modeling and Forecasting in Urban Areas. Proceedings of the 89th AMS Annual Meeting, 2009

Furberg M, Steyn DG, Baldi M (2002) The climatology of sea breezes on Sardinia. Int J Climatol 22:917-932. https://doi.org/10.1002/joc.780

Gille ST (2003) Measuring the sea breeze from QuikSCAT Scatterometry. Geophys Res Lett 30:1114. https://doi.org/10. 1029/2002GL016230

Huang M, Gao Z, Miao S, Xu X (2016) Characteristics of sea breezes over the Jiangsu coastal area, China. Int J Climatol 36:3908-3916. https://doi.org/10.1002/joc.4602

IBGE (2017) Population estimates 2017. Brazilian Institute for Geography and Statistics

INMET (2016) Brazilian National Meteorological Weather Institute

Khan B (2010) Sea breeze circulation in the Auckland Region: observational data analysis and numerical modelling. Ph.D. thesis, University of Canterbury

Kousky VE, Gan MA (1981) Upper tropospheric cyclonic vortices in the tropical South Atlantic. Tellus 33:538-551. https://doi.org/10.1111/ j.2153-3490.1981.tb01780.x

Lensky IM, Dayan U (2012) Continuous detection and characterization of the sea breeze in clear sky conditions using Meteosat Second Generation. Atmos Chem Phys 12:6505-6513. https://doi.org/10. 5194/acp-12-6505-2012

Lopes A, Lopes S, Matzarakis A, Alcoforado MJ (2011) The influence of the summer sea breeze on thermal comfort in Funchal (Madeira). A contribution to tourism and urban planning. Meteorol Z 20:553564. https://doi.org/10.1127/0941-2948/2011/0248

Mavrakou T, Philippopoulos K, Deligiorgi D (2012) The impact of sea breeze under different synoptic patterns on air pollution within Athens Basin. Sci Total Environ 433:31-43. https://doi.org/10. 1016/j.scitotenv.2012.06.011

Meir T, Orton PM, Pullen J, Holt T, Thompson WT, Arend MF (2013) Forecasting the New York City urban heat island and sea breeze during extreme heat events. Weather Forecast 28:1460-1477. https://doi.org/10.1175/WAF-D-13-00012.1 
Miller STK (2003) Sea breeze: structure, forecasting, and impacts. Rev Geophys 41:1011. https://doi.org/10.1029/2003RG000124

Naor R, Potchter O, Shafir H, Alpert P (2017) An observational study of the summer Mediterranean Sea breeze front penetration into the complex topography of the Jordan Rift Valley. Theor Appl Climatol 127:275-284. https://doi.org/10.1007/s00704-015-1635-3

Oke T (1987) Boundary layer climates. Routledge, Abingdon

Okoola REA (1978) Spatial distribution of precipitation in the Mombasa area of Kenya, Kenya. Meteorological Department, IMTR Res. Report, $1 / 78$

Oliveira AP, Bornstein RD, Soares J (2003) Annual and diurnal wind patterns in the city of São Paulo. Water Air Soil Pollut Focus 3:315. https://doi.org/10.1023/A:1026090103764

Panchal NS (1993) Onset characteristics of land/sea breeze circulation and its effect on meteorological parameters at a coastal site. Atmos 6:155-162

Papamanolis N (2015) The main characteristics of the urban climate and the air quality in Greek cities. Urban Clim 12:49-64. https://doi.org/ 10.1016/j.uclim.2014.11.003

Papanastasiou DK, Melas D (2009) Climatology and impact on air quality of sea breeze in an urban coastal environment. Int J Climatol 29: 305-315. https://doi.org/10.1002/joc. 1707

Papanastasiou DK, Melas D, Bartzanas T, Kittas C (2010) Temperature, comfort and pollution levels during heat waves and the role of sea breeze. Int J Biometeorol 54:307-317. https://doi.org/10.1007/ s00484-009-0281-9

Pereira EB, Martins FR, Gonçalves AR, Costa RS, Lima Francisco JL, Rüther R, Abreu SL, Tiêpolo GM, Souza JG, Pereira SV (2017) Brazilian atlas of solar energy. 2. ed. São José dos Campos. INPE

Perez GMP, Silva Dias MAF (2017) Long-term study of the occurrence and time of passage of sea breeze in Sao Paulo, 1960-2009. Int J Climatol 37:1210-1220. https://doi.org/10.1002/joc.5077

Phan TT, Manomaiphiboon K (2012) Observed and simulated sea breeze characteristics over Rayong coastal area, Thailand. Meteorog Atmos Phys 116:95-111. https://doi.org/10.1007/s00703-012-0185-9

Planchon O, Damato F, Dubreuil V, Gouery P (2006) A method of identifying and locating sea-breeze fronts in north-eastern Brazil by remote sensing. Meteorol Appl 13:225-234. https://doi.org/10.1017/ S1350482706002283

Radha Krishna Rao GSV, Purnachandra Rao M (2005) Influence of sea breeze on line-of-sight links located in Vishakapatnam. A U J T 9:89-98

Reddy LRG, Reddy BM (2007) Sea breeze signatures on line-of-sight microwave links in tropical coastal areas. Radio Sci 42. https://doi. org/10.1029/2006RS003545
Sánchez-Ccoyllo O, Silva Dias P (2000) Observational and numerical study of the sea breeze in São Paulo. In: I Brazilian Congress of Meteorology. Rio de Janeiro. (In Portuguese)

Sasaki Y, Matsuo K, Yokoyama M, Sasaki M, Tanaka T, Sadohara S (2017) Sea breeze effect mapping for mitigating summer urban warming: for making urban environmental climate map of Yokohama and its surrounding area. Urban Clim 24:529-550. https://doi.org/10.1016/j.uclim.2017.07.003

Seto D, Clements CB (2011) Fire whirl evolution observed during a valley wind-sea breeze reversal. J Combust 2011:1-12. https://doi. org/10.1155/2011/569475

Simpson JE (1966) Aerial and radar observations of some sea-breeze fronts. Weather 22:306-316

Simpson JE (1994) Sea breeze and local winds. Cambridge University Press, Cambridge

Simpson JE, Mansfield DA, Milford JR (1977) Inland penetration of seabreeze fronts. Q J R Meteorol Soc 103:47-76. https://doi.org/10. 1002/qj.49710343504

Teli M (2003) Main characteristics of sea/land breezes along the eastern coast of the Northern Adriatic. Geofizika 20:75-92

Thompson WT, Holt T, Pullen J (2007) Investigation of a sea breeze front in an urban environment. Q J R Meteorol Soc 133:579-594. https:// doi.org/10.1002/qj.52

Vemado F, Pereira Filho AJ (2016) Severe weather caused by heat island and sea breeze effects in the metropolitan area of Sao Paulo, Brazil. Adv Meteorol 2016:1-13. https://doi.org/10.1155/2016/8364134

Verejão-Silva MA (2001) Meteorology and climatology. INMET, Brasilia (In Portuguese)

Yamato H, Mikami T, Takahashi H (2017) Impact of sea breeze penetration over urban areas on midsummer temperature distributions in the Tokyo metropolitan area. Int J Climatol 37:5154-5169. https://doi. org/10.1002/joc. 5152

Yimin M, Lyons TJ (2003) Recirculation of coastal urban air pollution under a synoptic scale thermal trough in Perth, Western Australia. Atmos Environ 37:443-454. https://doi.org/10.1016/S13522310(02)00926-3

Yoshikado H (1990) Vertical structure of the sea breeze penetrating through a large urban complex. J Appl Meteorol 29:878891. https://doi.org/10.1175/1520-0450(1990)029<0878: VSOTSB $>2.0 . \mathrm{CO} ; 2$

Zhu M, Atkinson BW (2004) Observed and modelled climatology of the land-sea breeze circulation over the Persian Gulf. Int J Climatol 24: 883-905. https://doi.org/10.1002/joc.1045 